\title{
RISK ANALYSIS USING VALUE AT RISK METHOD ON BITCOIN AND JKSE PERIOD 2017-2019
}

\author{
Risty Mega Pramadita*1, Nora Amelda Rizal ${ }^{2}$ \\ Universitas Telkom, Indonesia*12 \\ ristypramadita@gmail.com ${ }^{\star 1}$, norarizal@telkomuniversity.ac.id ${ }^{2}$
}

\begin{abstract}
This research is motivated by Bitcoin that tends to be used as an alternative investment tool, and stock which is one of the most popular investment tools in the investment world. Both of these investments have characteristics of high fluctuating price movements. Thus, this study agrees to examine how much risk is faced by investors when choosing to invest in Bitcoin and Jakarta Composite Index (JKSE), using the Value at Risk ( $\mathrm{VaR}$ ) method. This research is using $\mathrm{VaR}$ calculation to estimates losses on an asset with a certain level of confidence and in a certain period and involves the GARCH model to estimate volatility. This research is used secondary data consisting of daily price data of Bitcoin obtained from coingecko.com and JKSE obtained from finance.yahoo.com. The research period is from January 1, 2017, to December 31, 2019. The results showed that Bitcoin has a higher risk compared to JKSE, which is about five times higher.
\end{abstract}

Keywords: Bitcoin, JKSE, Value at Risk, GARCH, Investment

\section{INTRODUCTION}

One of the digital innovations in the world of finance is the emergence of Bitcoin. Bitcoin is the pioneer of a decentralized peer-to-peer payment system that is fully controlled by users without any central authority (bitcoin.org, 2019). Apart from being the first cryptocurrency, Bitcoin has received the most widespread attention and popularity (Macauley, 2019).

Although Bitcoin was originally conceived as an alternative payment tool, Bitcoin is now seen and used as an alternative investment tool. The value of Bitcoin tends to be influenced by the amount of market demand and supply and is not influenced by the political conditions of a particular country, thus some people consider Bitcoin an attractive investment tool (Wijaya \& Darmawan, 2017).

Meanwhile, in Indonesia, the use of bitcoin is just as an investment tool (Aldin, 2018). Bitcoin is an investment vehicle that offers attractive opportunities in the potential of profit, but also has a high potential risk of creating losses due to its fluctuating value characteristics.

When placing Bitcoin as an investment tool and considering the perceptions of the risk posed by Bitcoin for investors, on the other hand, stocks are one of the risky investment assets (Tandelilin, 2010). The performance of stock investment will be directly related to the success of the stock issuing company so that investment in stocks tends to be riskier (Bodie et al., 2014). Meanwhile, in general, JKSE is a representative value of all stock prices listed on the Indonesia Stock Exchange (Halim, 2015).

On the other hand, an important thing that must always be considered in investing is how much risk must be borne from an investment (Tandelilin, 2010). One of the widely used risk measurement tools is Value at Risk $(\mathrm{VaR})$. Banks, brokerage companies, investment funds, and even nonfinancial companies use the VaR method to measure their financial risk (Jorion, 2007).

Stavroyiannis (2018) through his research that implements Value at Risk calculations to measure risk in Bitcoin, and then compares the risk calculation with the S\&P 500 index and gold prices. Then, research conducted by Uyar \& Kahraman (2019) which they use Value at Risk to analyze the comparison of the 
level of risk that is owned by Bitcoin and major conventional currencies.

Thus, this study is intended to determine how much risk or loss is faced when choosing investments in Bitcoin and stocks and to compare the risks of the two research objects, based on the calculation of the Value at Risk method.

Investment is sacrificing something valuable now in the hope of getting benefits from these sacrifices in the future (Bodie et al., 2014). The basis for investment decisions consists of the expected rate of return, the level of risk, and the relationship between return and risk (Tandelilin, 2010).

Stock is a sign of someone's participation or ownership of an entity in a company or limited liability company (Darmadji \& Fakhruddin, 2011).

There is a market demand that uses Bitcoin as an investment tool. Someone buys Bitcoin and will hold it in the hope that the price of Bitcoin will increase in the future, and he can sell it (Narayanan et al., 2016). When considering the behavior of high price fluctuations, Bitcoin appears to be more likely as an investment tool than as a reliable payment tool (European Central Bank, 2015).

Return is the benefit of an investment (Tandelilin, 2010). There is an expected return and actual return (realized return). Hartono (2013) expected returns have not occurred, while actual returns have already occurred.

Tandelilin (2010) risk is the difference between expected return and actual return. The greater the risk of an asset, the greater the expected return on that asset. There are 3 kinds of investor preferences for risk, namely investors who like risk (risk-seekers), investors who are risk-neutral, and investors who do not like risk (risk-averter) (Halim, 2015).

Choudhry (2013) Value at Risk $(\mathrm{VaR})$ is the maximum possible loss that can occur to an asset, which is expressed in monetary terms, over a certain period, and with a level of confidence chosen by the user. This research calculates VaR used the Variance-Covariance method, which is based on the assumption of a normal distribution. Risk factors are processed in such a way that they are normally distributed (Jorion, 2007). The method can be implemented quickly and easily used together with volatility (Hull, 2010).

Volatility is the standard deviation of returns over a certain period. In financial market terms, volatility is a measure of how much the price of an asset moves each day or week, or month (Hull, 2010). In general, assets that show high volatility or volatility tend to present a higher risk (Choudhry, 2013).

\section{METHODS}

The type of research of this research is descriptive. This research is quantitative because it uses quantitative data. Meanwhile, based on the implementation time, namely the time series. The population in this research, namely Bitcoin and JKSE. In this research, the sampling technique used is purposive sampling, which is the daily closing price of Bitcoin in the period from January 2017 to December 2019 and JKSE in the period from January 2017 to December 2019.

This research uses secondary data, Bitcoin price data is obtained from coingecko.com, and JKSE data is obtained from finance.yahoo.com.

The first stage of the data analysis technique in this research is to calculate the return of the daily closing price of Bitcoin and JKSE during the research period, using the following formula.

$$
R_{t}=\frac{P_{t}-P_{t-1}}{P_{t-1}}
$$

Where $R_{t}$ is the return of the asset, $P_{t}$ is the price of the asset at time $\mathrm{t}$, and $P_{t-1}$ is the price of the asset at time t-1. After that, the return data was tested, with tests consisting of stationarity test, normality test, and heteroscedasticity 
test. The stationarity test is carried out to confirm whether the return data is stationary (Winarno, 2015). The normality test is carried out to confirms whether the return data is normally distributed or not (Winarno, 2015). Jorion (2007) if the normality test performed shows the return data is not normally distributed, then the value of alpha is corrected using Cornish Fisher Expansion. The heteroscedasticity test was carried out to find out whether the return data has constant variance or not (Winarno, 2015).

Next, performs volatility calculations using the Generalized Autoregressive Conditional Heteroscedastic (GARCH) model. Tsay $(2010)$ the form of the GARCH equation $(p, q)$ is as follows.

$$
\sigma_{t}^{2}=\alpha_{0}+\sum_{i=1}^{p} a_{i} a_{t-i}^{2}+\sum_{j=1}^{q} \beta_{j} \sigma_{t-j}^{2}
$$

This states that the conditional variance $\left(\sigma_{t}^{2}\right)$ depends not only on the squared residual in the previous period $\left(a_{t-i}^{2}\right)$ but also on the conditional variance in the previous period $\left(\sigma_{t-j}^{2}\right)$ (Gujarati \& Porter, 2012). If the sum of $a_{i}$ and $\beta_{j}$ approaches one, it requires a special form of $\mathrm{GARCH}$, namely IGARCH (Jorion, 2007). The best model is selected based on that has the smallest value of the Akaike Information Criterion (AIC), Schwartz Information Criterion (SIC), Hannan Quinn Criterion (HQIC) (Ariefianto, 2012).

Then, the last step is to calculate the Value at Risk (VaR) for Bitcoin and JKSE using the following formula.

$$
\operatorname{VaR}=W * \sigma * \alpha * \sqrt{T}
$$

Where $W$ is exposure, $\sigma$ is volatility, $\alpha$ is the confidence level, and $T$ is the holding period (Jorion, 2007). This study calculates the VaR for Bitcoin and JKSE using a 95\% confidence level. For the return data that shows not normally distributed, the value of alpha is corrected by Cornish Fisher Expansion, while for the return data that shows normally distributed, the value of the alpha is 1,645 (Jorion, 2007).

\section{RESULTS AND DISCUSSION The Testings of Return Data}

At this step, a stationarity test, a normality test, and a heteroscedasticity test are performed. The stationarity test shows that the Bitcoin return data and the JKSE return data are stationary. The normality test shows that the Bitcoin return data and the JKSE return data are not normally distributed. Thus, the alpha value for Bitcoin and JKSE is corrected using the Cornish Fisher Expansion. The stationarity test shows that the Bitcoin return data on Bitcoin and the JKSE return data are heteroscedastic.

\section{Volatility Estimation}

Based on the results of the heteroscedasticity test which shows that the Bitcoin return data and the JKSE return data are heteroscedastic, the volatility estimation is performed using the GARCH model.

Table 1. The Results of Volatility Estimation of Bitcoin and JKSE

\begin{tabular}{cr}
\hline Investment & Volatility \\
\hline Bitcoin & 0,047439 \\
JKSE & 0,007714 \\
\hline \multicolumn{2}{c}{ Source: processed data $(2020)$}
\end{tabular}

In this research, the best model for estimating the volatility of Bitcoin, namely IGARCH $(2,1)$ which is resulting in the equation becomes $\sigma_{t}^{2}=0+$ $0,129470 a_{t-1}^{2}-0,102649 a_{t-2}^{2}+$ $0,973179 \sigma_{t-1}^{2}$, and the best model for estimating the volatility of JKSE, namely IGARCH $(1,1)$ which is resulting in the equation becomes $\sigma_{t}^{2}=0+$ $0,034183 a_{t-1}^{2}+0,965817 \sigma_{t-1}^{2}$. Based on the results, it shows that Bitcoin has a higher level of volatility compared to JKSE. 


\section{Value at Risk Calculation}

After the testings of return data and volatility estimation have been done, Value at Risk (VaR) calculation for Bitcoin and JKSE can be performed.

Table 2. The Results of VaR for Bitcoin and JKSE

\begin{tabular}{cc}
\hline Investment & VaR \\
\hline Bitcoin & IDR22.119.529,48 \\
JKSE & IDR4.298.006,35 \\
\hline \multicolumn{2}{c}{ Source: processed data (2020) }
\end{tabular}

This research uses IDR100.000.000 as the assumption of the amount of money invested and 10 trading days as the holding period.

Based on the results, it shows that Bitcoin has a higher $\mathrm{VaR}$ compared to JKSE. The Value at Risk of Bitcoin is IDR22,119,529.48. On the other hand, The Value at Risk of JKSE is IDR4,298,006.35.

The higher VaR Bitcoin indicates that the amount of risk (loss) that must be borne or the level of risk offered when choosing to invest in Bitcoin is higher than JKSE.

\section{CONCLUSION}

The findings show that Bitcoin has a higher VaR compared to JKSE, which is about five times higher. This also shows that the level of risk that Bitcoin has is higher than JKSE. That higher risk can also be seen with the higher volatility value of Bitcoin compared to JKSE. However, by using the VaR calculation, the risk of Bitcoin and JKSE can be explained in a form easier to understand. Therefore, the VaR calculation can describe the risk level of each investment and compare which one is riskier. Based on the comparison that has been obtained, it can be concluded that Bitcoin tends to be intended for investors who have a high tolerance for risk. The higher level of risk of Bitcoin compared to JKSE is supported regarding the characteristic of Bitcoin which does not have an underlying asset that underlies the price, so its value is very volatile. On the other hand, a higher risk level also illustrates a higher potential profit that is offered by the asset.

\section{REFERENCES}

Aldin, I. U. (2018). Popularitas Bitcoin di Indonesia Kalahkan Malaysia hingga Prancis. https://katadata.co.id/berita/2018/ 10/16/popularitas-bitcoin-diindonesia-kalahkan-malaysiahingga-prancis

Ariefianto, M. D. (2012). Ekonometrika: Esensi dan Aplikasi dengan Menggunakan Eviews. Jakarta: Erlangga.

bitcoin.org. (2019). Pertanyaan yang Sering Diajukan. https://bitcoin.org/id/faq

Bodie, Z., Kane, A., \& Marcus, A. J. (2014). Manajemen Portofolio dan Investasi (9th ed.). Jakarta: Salemba Empat.

Choudhry, M. (2013). An Introduction to Value at Risk (5th ed.). Chichester: John Wiley \& Sons.

Darmadji, T., \& Fakhruddin, H. M. (2011). Pasar Modal Indonesia (3rd ed.). Jakarta: Salemba Empat.

European Central Bank. (2015). Virtual currency schemes - a further analysis.https://www.ecb.europa. eu/pub/pdf/other/virtualcurrencysc hemesen.pdf

Gujarati, D. N., \& Porter, D. C. (2012). Dasar-dasar Ekonometrika (5th ed.). Jakarta: Salemba Empat.

Halim, A. (2015). Analisis Investasi di Aset Keuangan. Jakarta: Mitra Wacana Media.

Hull, J. C. (2010). Risk Management and Financial Institutions (2nd ed.). United States: Pearson.

Hartono, J. (2013). Teori Portofolio dan Analisis Investasi (8th ed.). Yogyakarta: BPFE.

Jorion, P. (2007). Value at Risk: The New Benchmark for Managing Financial Risk (3rd ed.). Singapore: McGraw-Hill. 
Macauley, E. (2019). What Are the Most Popular Cryptocurrencies?. https://sba.thehartford.com/financ e/cryptocurrency/what-are-themost-popular-cryptocurrencies/

Narayanan, A., Bonneau, J., Felten, E., Miller, A., \& Goldfeder, S. (2016). Bitcoin and Cryptocurrency Technologies Draft Feb 2016. Princeton University Press. https://doi.org/10.1016/j.molliq.20 18.04.063

Stavroyiannis, S. (2018). Value-at-risk and related measures for the Bitcoin. Journal of Risk Finance, 19(2), 127-136. https://doi.org/10.1108/JRF-072017-0115
Tandelilin, E. (2010). Portofolio dan Investasi: Teori dan Aplikasi (1st ed.). Yogyakarta: Kanisius.

Tsay, R. S. (2010). Analysis of Financial Time Series (3rd ed.). United States: Wiley.

Uyar, U., \& Kahraman, I. K. (2019). The risk analysis of Bitcoin and major currencies: value at risk approach . Journal of Money Laundering Control, 22(1), 38-52. https://doi.org/10.1108/JMLC-012018-0005

Wijaya, D. A., \& Darmawan, O. (2017). Blockchain: Dari Bitcoin untuk Dunia. Jakarta: Jasakom.

Winarno, W. W. (2015). Analisis Ekonometrika dan Statistika dengan Eviews (4th ed.). Yogyakarta: UPP STIM YKPN. 